\title{
Non-existent states with strange institutions
}

\author{
Kristóf Gosztonyi
}

\section{Introduction}

$\mathrm{T}$ HE SEPARATIST CROATIAN Republic of Herceg-Bosna is an especially opaque phenomenon even taking into account the usual obscurity of Bosnian events. As fighting erupted in Bosnia-Herzegovina, Croatian Forces under the command of the Herceg-Bosna authorities fought together with the fledgling troops of the Bosnian government against the Serb aggression. Rivalries between Bosnian Croats and Bosniaks, which seemed to have been present from the beginning of their alliance (Halilovic 1997), led to increasingly violent clashes in January 1993 and to full-scale war four months later. At the height of this war (28 August 1993) the Croat Community of Herceg-Bosna transformed itself into a Republic and declared its independence. Military losses and international pressure compelled Franjo Tudjman, the President of the Republic of Croatia, to pressure Bosnian Croats to sign a peace agreement with the Bosnian central government in the spring of 1994, the so-called 'Washington Agreement'.

Until the signing of the Washington Agreement, Herceg-Bosna was a 'normal' secessionist pseudo-state with a dubious and authoritarian leader, Mate Boban, a more or less efficient and hierarchical wartime administration, and an increasingly centralised military corps (the HVO). In the course of the peace talks, Mate Boban was forced to resign and Krezimir Zubak, a previously unknown politician, took his place.

At the time of commencing fieldwork in February 1996, the impression gained from discussions differed strongly from the one-man-dominated parastate which had been described previously. Herceg-Bosna, though always a disputed and dubious political unit, seemed to be an obscure and undefined entity which gained a clear shape only if nationalist issues were touched upon. If asked about power holders, the names of politicians, military leaders and criminals were mentioned repeatedly, but none of them seemed to be anything other than second- or third-rank as far as political power was concerned. 
So what happened? How was this amorphous and decidedly nationalistic political monster created? It may be argued that a general lesson can be learned from the Herceg-Bosna case.

\section{Hypothesis}

The major problem of Herceg-Bosna is that to the outside world it says that it is not a state, but it actually acts like a state and says it is to its population. This line of thought leads to an examination of the interaction of an outside agency (the international community) with the local political structures.

The impact of changes induced by the simple interaction between a hegemonic external agency and local structures can be extremely far-reaching. A total transformation of political systems can result. Usually an increase in centralisation and bureaucratic control is expected as a consequence of this development. This phenomenon has been repeatedly observed by scholars and is part of the common- sense knowledge of social sciences (Bierschenk 1984; Evers and Schiel 1988; Spittler 1981; Sigrist 1979, etc.).

These external interventions have been characterised by an authoritarian and undemocratic mindset. The end of the Cold War saw the emergence of a new, 'soft' type of intervention, based on democratic principles and an aversion to overt engagement. International engagement still has unintended effects. However, under certain circumstances, recent interventions seem to effect a decentralisation of power and responsibility rather than its centralisation. HercegBosna is such a case.

Modern (peacekeeping) interventions take place in a political universe, the determining factors of which are: (a) traditional 'Realpolitik', (b) democratic principles, (c) human rights and (d) an aversion to overt engagement owing to domestic political concerns.

It may be argued that under such circumstances a diffusion of power can take place in the political entity under pressure. This is what happened in HercegBosna. Four conditions seem to contribute to such a diffusion of power owing to outside pressure:

- A relatively restrained foreign intervention.

- A tendency on the side of the interveners to address pre-existing political structures (instead of appointing new ones) or to accept new political structures legitimised by 'democratic' elections.

- A willingness on the side of the interveners to hold the representatives of the local political structures responsible for certain policy failures and human rights abuses.

- A strong identity and a common sentiment among the recipients of the foreign intervention that the aims of the intervention are not just. 
If the above conditions are present, the diffusion of power and responsibility takes place as an effect of the following four mechanisms:

- The appointment of weak leaders (this strategy is conscious and rational on the level of group interests).

- The conscious dismantling of personal power by some politicians.

- The loss of legitimacy of politicians who bow to external pressure.

- The conscious creation of an institutional 'jungle' in order to diffuse responsibility.

The historical genesis of Herceg-Bosna will be briefly described first, and subsequently, its current amorphous condition will be treated in detail.

\section{Herceg-Bosna: a normal separatist state}

The first free elections in Bosnia-Herzegovina in 1990 resulted in a clear victory for the ethnic parties. The distribution of the votes between the national parties is almost identical to the national distribution of Bosnia-Herzegovina: 43 per cent Muslims, 31 per cent Serbs, 17 per cent Croats and 6 per cent Other (most of whom described themselves as being Yugoslavs).

When war broke out in 1992 the three leading national parties took over the state and organised the spontaneously forming defence groups into a structured military system. For the Croats the leading national party was the Croatian Democratic Community of Bosnia-Herzegovina, the HDZ BiH - a party closely connected to the ruling Croatian party, the HDZ.

Extremist forces within the HDZ BiH linked up and were supported by extremist groupings in Croatia planning to establish a Greater Croatia through the annexation of parts of Bosnia-Herzegovina. As a result of this hard-line conspiracy within the HDZ, the Croatian Community of Herceg-Bosna (HZ HB) was founded on 18 November 1991. The aim of the HZ HB was to protect the interests and historical territories of all Croat people, though it still claimed to be committed to a unified Bosnia-Herzegovina. The founding document already listed the regions of which it claimed to be composed and mentioned the town Mostar as its seat (Narodni List HZ Herceg-Bosna 1991).

The president of the newly founded HZ HB was Mate Boban. Soon afterwards, in February 1992, in a coup-style takeover Boban also became the president of the HDZ BiH and begin the cleansing of the party of liberal, pro-Bosnian elements. This coup thus marked a change in Bosnian-Croat policies concerning their Bosniak allies. Another significant event in this respect was the assassination of Bla Kraljevic, the leader of the paramilitary organisation the HOS (Hrvatske ombrambene snage - Croatian Defence Forces). He was killed in the summer of 1992 near Mostar and his organisation was disbanded following this. What was remarkable about the murder is that Kraljevic and the HOS, a military 
group of the extreme right, supported the continued alliance of Croats and Bosniaks against the Serbs.

The first significant clashes between the Bosnian Croat Army (HVO) and the Bosniak-dominated Bosnian government forces (ARBiH) erupted in Central Bosnia in the beginning of 1993 and were followed by a counter-offensive of the ARBiH somewhat later. The heavily outnumbered Croats suffered heavy losses.

Throughout these skirmishes the situation around Mostar and in Herzegovina remained relatively calm. Nominally the HVO and ARBiH were still allies in this region. This changed on 9 May 1993 when the HVO launched a fullscale, but not very successful attack on the mainly Bosniak-dominated east side of Mostar.

A nine-month-long bloody war ensued between the former allies. During this war even those areas which until then had escaped such atrocities were ethnically cleansed. The result was three, nationally homogeneous regions - one Serb, one Croat and one Bosniak. At the height of this war, 28 August 1993, the Croatian Community of Herceg-Bosna was transformed into the Croat Republic of Herceg-Bosna and its independence was declared. Croatia reacted positively.

For the rest of 1993 the Croats continued to suffer heavy losses especially in Central Bosnia, where the previously numerous Croats were now surrounded in a few embattled enclaves. Additionally foreign and domestic Croatian pressure was increasing on President Tudjman to change his policies towards Mate Boban and Herceg-Bosna. In February 1994 Mate Boban was forced to resign. His place was taken by 'an anonymous politician, Kresimir Zubak' (BOSNET 4 March 1994).

Still in February a ceasefire was brokered between Bosniaks and Croats and on 1 March 1994 the Washington Agreement was signed. The Agreement envisaged the foundation of a Federation based on Swiss-style cantons (four Bosniak, two Croat, two Mixed and a special Sarajevo district). The Federation would eventually join in a confederation with Croatia. 'Zubak said after taking office that a confederation with Moslems was "possible, even desirable"” (BOSNET 4 March 1994).

This marks the beginning of intense international involvement in the Bosnian War and also of the amorphous state of Herceg-Bosna. Before addressing this topic, however, the political structures of Herceg-Bosna prior to the diffusion of political authority in this entity will be examined.

\section{Political structures in Herceg-Bosna until the end of the war}

In the period until the fall of Mate Boban, Herceg-Bosna was a normal separatist state emerging from the chaos of the dissolution of the former Yugoslavia. Herceg-Bosna had, it seems, a functioning party apparatus and at its head an authoritarian leader, Boban. To demonstrate the difference between the emerging 
political authority and organisation (until February 1994) and the later state of 'disbanded' political control in Herceg-Bosna, two aspects of para-state politics have to be examined. First, the increasing unification and bureaucratisation of control over spontaneously formed military defence units and secondly, the political leadership and the relation of Herceg-Bosna to Croatia.

\section{Unification and bureaucratic control of paramilitary units}

Paramilitary units already began to be formed at the end of the 1980s as tensions between the federal partners of the Yugoslav state were increasing. In the initial period of the war, the military landscape was truly confusing. A report of the Hague War Crimes Tribunal summarises the situation accurately:

The Croatian Defence Council forces in Bosnia and Herzegovina are supported by the Croatian Army, local Croatian police, volunteer civilians and 'special forces' like the military wing of the Croatian Party of Rights (named after the former Ustashas of the Second World War, who also fought against the Serbs in the Krajina area). Other Croatian armed civilian forces operate essentially in local areas. (Report of the Hague War Crimes Tribunal: The military structure of the warring factions and the strategies and tactics they employ 1995)

In this initial phase of the war, there were still no efficient command structures; the relationship between the different units was not yet established. The subsequent evolution towards a unified command structure affected the different paramilitary groupings - the local Croat police, 'special forces' and local forces of armed citizens - in different ways.

Whereas the bringing together of police forces and the local militias under a unified command structure seems to have been relatively easy, the 'disciplining' of the 'special troops' deserves particular attention. In all the theatres of war in the former Yugoslavia a cleansing of such troops and of their individual leaders has taken place. In Croatia it occurred towards the end of the first war year in 1991 and the beginning of 1992. The Serb insurgent para-states (i.e. the Republika Srpska Krajina in Croatia and the Republika Srpska in Bosnia) and the Bosnian government all cleansed their militaries in the course of 1992 and 1993. 'These heroes were either killed, put in jail, or disciplined', wrote the war reporter, Vladimir Jovanovic (1995).

However, not all 'special troops' suffered the same fate. Only 'those paramilitaries disloyal to the ruling elite were caught by a wave of never solved murders'. Cooperative special troop leaders continued to participate in the fighting, and were occasionally redeployed for 'special tasks' such as ethnic cleansing or to break the 'remnants of the democratic opposition and independent media' (Jovanovic 1995).

Concerning Herceg-Bosna the elimination of Bla Kraljevic, the leader of 
HOS, fits into this same pattern. Other 'special troop' leaders, such as Mladen Naletilic Tuta, continued to exert influence and actually became one of the most powerful military leaders of Herceg-Bosna. Unlike Kraljevic, however, Tuta supported a split between the Croats and Bosniaks.

Thus, until the beginning of 1994, Herceg-Bosna seems to fit in the general pattern of all the warring parties. All these states increasingly began to unify their initially loose military units under a joint command and were thereby eliminating troublesome, independent-minded paramilitary units and their leaders. This process could not be completed in a short space of time and it is still ongoing. Additionally, it was probably never intended to be a completely finished process; semi-independent paramilitaries were a useful tool for doing the 'dirty work' of ethnic cleansing and terrorising the political opposition.

Nevertheless, it may be concluded that a movement towards the centralisation of power took place in Herceg-Bosna. If it was successful with regard to the armed forces it can be assumed to have been even more successful concerning other branches of the wartime administration of Herceg-Bosna. The next section examines the political leadership in Herceg-Bosna and the relations of HercegBosna with Croatia.

\section{Political leadership and the relations of Herceg-Bosna with Croatia}

As has been already stated, Mate Boban was a leader with authority. His steady rise, first to the post of the President of the Croatian Community of HercegBosna, then the President of the Bosnian HDZ and finally to the head of the selfproclaimed Croat Republic of Herceg-Bosna, shows his strong ambitions. In the course of his advance he reshaped the politics of the Bosnian Croats and of the $\mathrm{HDZ} \mathrm{BiH,} \mathrm{though} \mathrm{he} \mathrm{received} \mathrm{strong} \mathrm{support} \mathrm{for} \mathrm{this} \mathrm{project} \mathrm{from} \mathrm{the} \mathrm{Croatian}$ President, Tudjman and his Defence Minister, the Herzegovinian Gojko Susak, who died in April 1998.

Boban therefore must have held significant authority and even after his forced resignation he remained an influential figure in Herceg-Bosna until his death in the summer of 1997. His portrait hangs in the office of the Mostar Municipal Board of the HDZ. Without any doubt in 1992-93 he shaped Bosnian Croat politics. President Izetbegovic bitterly accused him of wanting to establish a 'Bobanistan'. Clearly he also saw Boban as wielding great power.

The actions of Boban supported Izetbegovic's views. In the course of 1993 he participated in the Geneva talks, and met for a round of secret negotiations with Karadjic where they attempted to carve up Bosnia and Herzegovina between Croats and Serbs. In other words, the actions of Boban indicate that he was an authoritarian leader with real power who was also treated that way by other politicians.

The further important question concerns the relationship of Croatia to 
Herceg-Bosna. It seems that President Tudjman had at least four instruments available to put pressure on Boban and Herceg-Bosna: the structure of the HDZ, personal networks through his Herzegovinian Defence Minister Gojko Susak, the military and financial aid Croatia was giving to Herceg-Bosna and the networks of the Croatian secret service (SIS) and its Bosnian-Croat counterpart the HIS.

Particularly in this period the Croatian leadership viewed Herceg-Bosna as its own territory. Even more revealing about the Croatian influence on HercegBosna in this period is the fact that facing mounting foreign and domestic pressure added with the deteriorating military situation in Central Bosnia, President Tudjman was able to force Boban to withdraw from his position as President of Herceg-Bosna at the beginning of 1994.

To summarise, Herceg-Bosna in the period before the beginning of 1994 was a nationalist para-state emerging from the chaos of the dissolution of the former Yugoslavia and later of Bosnia-Herzegovina. The disorderly, spontaneously formed units of this new state were, however, rapidly being transformed and integrated into an increasingly centralised, though never internationally recognised state. All this occurred under the leadership of an authoritarian leader, Mate Boban, who was able to shape the policies of the state and, it would seem, to enforce his decisions. He was treated accordingly by foreign statesmen. Moreover, the structures of the para-state Herceg-Bosna were being merged into Croatian structures of power, with Croatia being able to exert significant influence on Herceg-Bosnian events.

The question is, therefore, how did the breakdown of power, or at least the decentralisation of power, which is currently experienced by diplomats and foreign statesmen trying to deal with Herceg-Bosna, occur?

\section{Mysterious Herceg-Bosna}

Kresimir Zubak, the new President of Herceg-Bosna, stated after taking office in February 1994 'that a confederation with Moslems was "possible, even desirable"' (BOSNET 4 March 1994).

There was, however, little movement towards the implementation of the Federation of Bosnia and Herzegovina. The superstructure of the Federation was established but it remained without any effective power and without any institutions on the ground. No steps were made either towards the dismantling of Herceg-Bosna, 'a direct negation of the idea of the Federation'. Cooperation between Bosniaks and Croats was reduced to occasional joint military actions against the Serbs.

Some movement came with the signing of the Dayton Peace Agreement on 10-11 November 1995. The Dayton Agreement on Implementing the Federation of Bosnia and Herzegovina of 10 November 1995 confirmed the abolition of HercegBosna and set deadlines for the establishing of the cantons as agreed in the 
Washington Agreement. The dismantling of Herceg-Bosna was a complicated process of transferring the competencies of the para-state to the Federation and/or to the cantons.

Under the Dayton Agreement, Herceg-Bosna was to disappear within two weeks of the signing of the Agreement. But Herceg-Bosna was not dismantled. Croat officials referred to the fact that the institutions of the Federation were not yet functioning. A transfer of competencies would thus leave Croat areas in an administrative vacuum. Facing mounting international pressure various distracting and confusing steps were taken and some competencies were formally transferred to new ministries or cantons.

Finally, 'Kresimir Zubak, the former President of the Muslim-Croat Federation and a Croat member of the three-man Bosnian presidency [announced] that the Bosnian Croat para-state of Herceg-Bosna ceased to exist on 17 December, the same day that the Bosnian republican government transferred its functions to the federation' (Sito Sucic 20 December 1996). A little over one month later, on 27 January 1997, representatives of all Bosnian Croat associations met to set up a new Croat Community of Herceg-Bosna. The new community replaced the banned para-state of the same name (Sito Sucic, 28 January 1997). Obviously Herceg-Bosna had not ceased to exist.

Since 1997 further significant improvements have taken place, and cantons have been established. The establishing of the ethnically pure Croat cantons posed no problems. The establishing of the two mixed cantons, however, proved to be more difficult. In order to meet the Dayton Agreement deadlines all cantonal assemblies did hold meetings, though not very productive ones. Whole cantonal sessions could be spent with the discussion of such interesting topics as to what the flag of the canton should be. Unfortunately the mixed cantons may prove as powerless as the Federation as a whole.

While a number of joint institutions - among others a joint police force have been established, and one can see signs of increasingly coordinated joint action, in practice they still function as separate institutions. Thus, in a joint Federal Ministry the Croat head would give instructions to the Croat officials and the Bosniak head to the Bosniak officials.

As of 1999, the institutions of the Federation still did not function satisfactorily. The top-to-bottom strategy of establishing common institutions in BosniaHerzegovina is not a success. The orders of these institutions, which can be established only under significant international pressure, are not carried out. The blockade occurs on the one hand on an institutional level, e.g. the reestablishment of Herceg-Bosna, and on the other hand by individual level actors like policemen, administrative clerks, etc. who refuse to carry out the instructions issued by institutions which they do not consider legitimate.

Even though progress has been made in implementing the Federation, the general picture is still one of two separate para-states. The joint Croat-Bosniak 
institutions of the Federation wield little authority. But do the Herceg-Bosnian authorities hold power? Naturally, Herceg-Bosnian authorities are more powerful than any of the Federal institutions, but there is no centralised power or responsibility which would be usual for modern states.

However, the following indicators show the lack of coherent command structures, which are then discussed in greater detail:

- There is no strongly coordinated strategic action. Herceg-Bosna politics are mostly only able to act reactively, or to act in order to achieve simple objectives.

- The occasional total breakdown of hierarchical structures.

- An unconscious recognition of the loose command structures by the international community, as their representatives go to negotiate at a municipal levels.

\section{Lack of strategic action}

In addition to the usual political divisions within a party (e.g. hard-liners versus moderates) which usually appear at all levels of the party as vertical splits, and regional divisions, which are also quite frequent in most political organisations, in Herceg-Bosna a very strong division or chasm in a hierarchical sense may also be found. The leadership is frequently simply unable to impose its decisions on the hierarchically subordinate units.

A comparison with the Bosniaks is revealing. In the summer of 1997 the Office of the High Representative of the UN to Bosnia and Herzegovina (OHR), the main international organisation tasked with the implementation of the Dayton Agreement, increased its pressure on the Bosniak East-Mostarian leadership to evict some 150 Bosniak families from Croat houses near the former confrontation zone, but within ARBiH-held territory, the Bosniak leadership conceded. They had committed themselves to vacating the area in an internationally brokered agreement a few months earlier. Evacuating the 150 families was very unpopular among the population, but the leadership nevertheless went ahead with the project and succeeded. In the general scheme of Mostar politics, the Bosniak side appeared once again sufficiently cooperative, while the Croats remained the 'bad guys'. Compared with the Bosniak structures, the Croat side was unable to sacrifice short-term nationalist goals or achievements in order to gain longer-term political benefits.

\section{Breakdown of hierarchic structures}

An example of the breakdown of hierarchic structures occurred in early October 1998, when Bosniaks attempted a return to the strategically crucial village of Tasovcici. The reason for Tasovcici's strategic importance lies in its location on 
the major road leading from the Croatian Coast to Mostar. Additionally, there is a bridge of similar military importance spanning the Neretva. Immediately after the return took place, tensions flared and two days later the returnees were attacked with hand-grenades by a Croat mob after a demonstration organised by the Mayor of the Municipality. The attacks left one Bosniak dead and several wounded and increased international political pressure on the Croat side tremendously.

Probably because of the expected negative repercussions for the cause of Herceg-Bosna, a number of high-level Bosnian Croat politicians went to see Sir Martin Garrod, the Head of the Southern Office of OHR, in order, basically, to beg him to remove the Bosniak returnees from Tasovcici. They said they feared incalculable consequences if the returnees stayed. While they were still in discussions with Sir Martin, the first reports about the attacks on the returnees arrived. In the following days, the Croat Interior Minister of the Canton, who was one of the delegation asking Sir Martin to remove the returnees, completely lost control over the police administration of the municipality responsible for Tasovcici. The police there openly defied his instructions which were aimed at a de-escalation of the situation.

\section{Recognition of loose command structures by the international community}

Even though most international officials believed there was a clandestine and tightly organised hierarchy in Herceg-Bosna, when faced with a political problem in a certain Croat-controlled area, they usually try negotiating with all levels of decision making. Thus they approached the Croatian President, Franjo Tudjman, they held discussions with the Bosnian Croat leaders, i.e. Kresimir Zubak and later Ante Jelavic, as well as with cantonal and usually also municipal (!) heads. If there was a tight hierarchy within Herceg-Bosna, there would have been no need for high-level international representatives, such as, for example, the OHR Deputy High Representative Hanns Schumacher, to negotiate with the Mayor of the Croat-dominated Municipality of Stolac concerning the return of Bosniaks in the spring of 1997. The fact that high-level international officials repeatedly negotiated with mayors of municipalities reveals that they 'unconsciously' realised the true power of such low-level politicians within Herceg-Bosna.

\section{Institutional anarchy}

It is very difficult to show the partial absence of power in Herceg-Bosna, which has been hypothesised here. It is difficult to show the decentralisation and disintegration of power owing to the confusing presence of an administrative and party hierarchy which has created the impression of an organised political entity. 
To a certain extent Herceg-Bosna does present a normal picture - roads are built, business permits are issued, etc. Other aspects of a functioning state are, however, absent.

Another difficulty in proving the absence of centralised power is the possibility that an unknown strong man or a grouping of power holders might control events from behind the scenes - a conspiracy theory. Additionally, the politics of the region are full of lies, deceit and confusion.

Owing to these difficulties and a general lack of information the evidence presented here is sketchy and is drawn from a variety of sources. Furthermore, a major part of the argument is based on indirect evidence. Conflicts of interest between certain groupings or individuals who are suspected of having determinate power or authority may reveal hidden structures.

It is important to clarify what is meant by a 'lack of power'. It is clear that no social system has an unambiguously hierarchical and centralised power structure. What will be shown here is that a number of individuals and groupings can be found which all hold certain powers in Herceg-Bosna. The relative status of these actors, regarding the amount of influence and authority they wield, is that of more or less equals, it is anarchy within an oligarchy.

Several different social actors, in the widest sense of the word, are usually suspected of wielding or having wielded power in Herceg-Bosna, namely:

- the state of Herceg-Bosna, or in other words the administrative organisation of that state;

- the HDZ;

- Croatia, i.e. Franjo Tudjman or Gojko Susak, the now deceased Croatian Defence Minister;

- criminals like Mladen Naletilic Tuta;

- the general population.

However, on several occasions all them have been proven incapable of imposing their will on the other power factors. Decision making frequently tends to become collective, carried out by bodies of the Assemblies of Municipal Boards of the HDZ. Finally, a number of power holding actors (organised crime, municipal boards of the HDZ, the general population, etc.) have the capability to block certain political developments. This capability can function as an effective veto.

The question is, then, how did this decentralisation of power occur? The phenomena of power decentralisation described above need to be connected to the actions of the international community. In this concluding section, an attempt is made to show how the international intervention caused the decentralisation of power in the region. 


\section{The international community}

It has been shown that in the course of its historical evolution, Herceg-Bosna, emerging from the total chaos of the initial phase of the Bosnian war, entered a stage of increasing centralisation of power. This occurred from the beginning of 1992 until the end of 1993 under the leadership of Mate Boban.

Following the signing of the Washington Agreement, a change in the leadership of Herceg-Bosna took place. This period of Herceg-Bosnian history was characterised by a decentralisation of power and decision making, though its main nationalist goals remained untouched. It was also argued that modern international pressure is effective, though its effects are often not immediately obvious. Usually they manifest themselves only with a certain time lag.

The dissolution of power in Herceg-Bosna occurred as an unintended result of international pressure. However, this is not easy to establish as the kind of social mechanisms which are supposed to be operative in the process of power decentralisation are difficult to describe. The conditions for a Herceg-Bosna style dissolution of power, as discussed already, are outlined below:

- Owing to a relatively restrained international intervention (the unwillingness to suffer losses, etc.) the main instruments of enforcement are positive and negative economic sanctions. Military threats or sanctions are rare.

- The willingness on the side of the interveners to address pre-existing political structures (instead of appointing new ones) or to accept new political structures legitimised by 'democratic' elections.

- The willingness on the side of the interveners to hold the representatives of the local political structures personally responsible for certain policy failures and human rights abuses. With regard to this aspect of the international intervention, the main instrument available to the international community has been the Hague War Crimes Tribunal and more generally the United Nations (UN).

- A strong identity and a common sentiment among the recipients of the foreign intervention that the aims of the intervention are not just.

How did Croat and local Herceg-Bosnian politicians react to the approach of the international community as described in the first three conditions, given the strong common identity in the region as referred to in the fourth? The following mechanisms were suggested in the introduction:

- the appointment of weak leaders (this strategy is conscious and rational at the level of group interests);

- the conscious blurring of the chain of command or even dismantlement of personal power by some politicians;

- the loss of legitimacy of politicians who bowed to external pressure; 
- the conscious creation of an institutional 'jungle' in order to diffuse responsibility.

The reality of these social mechanisms as a response to international pressure can only be surmised, because these strategies are formed on the basis of considerations not explicitly formulated. It would be naive to expect politicians to acknowledge having concealed their channels of authority or even that they consciously dismantled their personal power. Therefore, the different mechanisms proposed above as being a response to international intervention and as contributing to the current state of the dissolution of effective power, are elaborated upon through relevant examples.

\section{Appointment of weak leaders}

Two Croat leaders, Kresimir Zubak, the first President of the Federation of Bosnia and Herzegovina, and Mijo Brajkovic, the former Mayor of West Mostar, seem to fall into this category. Both were previously relatively unknown and both had a reputation for being moderate. It seems that neither of them was usually capable of enforcing agreements made with the representatives of international institutions. Weak political leaders often find themselves caught in a rather uncomfortable situation: on the one hand they are pressured by the international community, and on the other by their own national hard-liners.

\section{Obscuring command structures and dismantling personal power}

The Hague War Crimes Tribunal wrote the following concerning the blurring of command structures, particularly with regard to the unclear hierarchical relationship between different military units and between certain units and the national leadership: 'such a structure and the strategies and tactics employed help to blur the chain of command and conceal responsibility. This concealment may well be intended by some of the parties to provide a shield of plausible deniability.'

According to the United Nations High Commissioner for Refugees (UNHCR) Officers who served in the area during the Bosniak-Croat War soon after the establishing of the Hague War Crimes Tribunal, the Mayor of the west Herzegovinian town of Capljina began to refer international officials to his Deputy, Krunoslav Kordic when approached about the concentration camp for Bosniaks. Markovic claimed he was not responsible.

The reaction was the severance of formal chains of command to Bosnian Croats and a switch to an increasingly clandestine manipulation of HercegBosnian politics. It is difficult to imagine that the dismantling of official channels of authority would not also result in a consequent loss of power. 
A similar concealing, blurring and conscious dissolution of organised command can be suspected as having taken place at all levels of politics. However, the observation that decision makers do occasionally conceal authority, even at the cost of effectively dismantling the chain of command, can be accepted as valid for the situation with which Herceg-Bosna is currently confronted.

\section{Loss of legitimacy for 'compromisers'}

If leaders were strong prior to their contact with international actors, their compromising attitude would probably make them weak. A 'compromising' attitude means here a tendency to give in to pressure from international actors. The loss of power for such a 'compromiser' would probably happen gradually. Increasingly their subordinates would refuse to execute orders which they considered unjustified or harmful to national goals.

In a number of instances Herceg-Bosnian Croat police refused to execute the orders of Croat politicians, for example participating in Joint Police Patrols with Bosniaks in Mostar or prosecuting the individuals who evicted non-Croats from West Mostar (i.e. the Croat part of the town). The case of Ivan Prskalo, the Mayor of Mostar, provides another example. With regard to the expulsions 'Prskalo assured the city council during its December 14 session that these criminal acts [i.e. the expulsions of non-Croats from their apartments in West Mostar] would cease. The next day the expulsions continued' (BOSNET 1997).

By the same token, weak leaders can be forced to adopt more nationalist attitudes. Brajkovic, the former Mayor of West Mostar was originally regarded as a moderate. After he called for the infamous 'peaceful' demonstration against the European Union Administrator of Mostar, Hans Koschnick which, some foreign diplomats say, he could not avoid, he completely lost all credibility in the eyes of international actors. He is now generally known as a Croat hard-liner. He had nothing more to lose with regard to the international community.

\section{Conscious creation of an institutional 'jungle'}

This is the mechanism for which it is most difficult to provide 'hard' evidence. The argument that a confusing set of institutions, committees and subcommittees can easily be used by Herceg-Bosnian politicians eager to divert attention from themselves rests on two clues and on the general plausibility of the notion.

International officials told me repeatedly in interviews that they were convinced that when local politicians wanted to obstruct constructive negotiations they often forced the foundation of a working group of 'experts'. Such meetings were truly frustrating and rarely came up with anything constructive. Another hint as to the conscious use of an 'institutional jungle' to conceal responsibility is even more vague. It seems that Herceg-Bosnian institutions are restructured 
and their personnel changed with a confusing frequency. The names of certain functionaries turn up again and again in different positions.

It has to be noted, however, that the presence of such a highly complex institutional structure as prescribed in the Dayton Agreement, combined with the institutional reality of Herceg-Bosna is in itself sufficient to completely blur competence.

In summary, the above mechanisms of avoiding compromise when faced with international pressure can only be successful given the current form of restrained international intervention and by the presence of a strong common identity in Herceg-Bosna. The restrained character of international intervention is important in opening up the avenues of local resistance mentioned above, because its sanctions are relatively 'soft', and it shows little commitment to completely purging the Herceg-Bosnian political elite and replacing it with one more acceptable to international actors. The problems of such a relatively weak approach were already apparent to Holbrooke during the negotiations. Accordingly he pushed for a stronger mandate of international organisations implementing the Dayton Agreement, e.g. for the International Police Task Force to have real policing functions and not just the role of monitoring the performance of the local police, and also for the NATO-led Implementation Force (IFOR) to have a more robust mandate (Holbrooke 1998).

Past interventions often did not have such constraints. Soviet occupation of Eeastern European countries replaced the entire ruling elite of those countries with communist cadres favourable to Soviet interests. Also US interventions in South America, for example, did not have many constraints. Economic pressure was frequently supplemented with all kinds of subversive US activities. With ruthless strategies interveners thus either created their own elite or gave a compromising, opportunistic new elite such powers that it could stabilise its position regardless of public acceptance.

Given the current restrained interventions on the one hand, and a strong identity and a common rejection of the aims of the intervention by the population being subjected to the intervention on the other, the Herceg-Bosnian style of resistance can be surprisingly effective. The reason for the success of resistance in areas with strong common identities when faced with a restrained intervention lies in the social sanctioning of potential collaborators. This way opportunistic elites, who would be willing to accept the resources of the foreign interveners to build up their own power base, are discouraged. This discouragment can take the form of 'shaming' collaborators, boycotting cooperation with them or can even include violent sanctions against them.

REFERENCES

Bierschenk, T. (1984), Weltmarkt, Außenabhängigkeit und Staatsformation in Südostarabien (Saarbrücken and Lauderdale). 
BOSNET (Bosnian Electronic Network) (1997), 7 January. Subject: BosNet Report: A Decisive Year Part 2., Online-publication, web 15 January 2002, www.bosnet.org/ archive.

BOSNET (Bosnian Electronic Network) (1994), 4 March. Subject: Bosnet News-3 March. Source: Reuters, www.bosnet.org/archive.

Evers, H. D. and T. Schiel (1988), Strategische Gruppen. Vergleichende Studien zu Staat, Bürokratie und Klassenbildung in der Dritten Welt (Berlin).

Halilovic, S. (1997), Lukava Strategija (Cunning Strategy) (Sarajevo).

Holbrooke, R. (1998), To End a War (New York).

Jovanovic, V, (1995), 'Paravojske jedinice' (Paramilitary units), Monitor, 14 April.

Narodni List HZ Herceg-Bosna (Official Gazette of the Croatian Community Herceg-Bosna) (1991), September.

Sigrist, C. (1979), Regulierte Anarchie. Untersuchungen zum Fehlen und zur Entstehung politischer Herrschaft in segmentären Gesellschaften, (Frankfurt/M.).

Sito Sucic, D. (1996), 'Herceg-Bosna said to be officially dismantled ...' OMRI Daily Digest, 20 December.

Sito Sucic, D. (1997), 'Step closer to establishing Croatian community of Herceg-Bosna?' OMRI Daily Digest, 28 January.

Spittler, G. (1981), Verwaltung in einem afrikanischen Bauernstaat (Wiesbaden).

United Nations Security Council (1994), S/1994/674- 27 May 1994, Final Report of the Commission of Experts. Established Pursuant to Security Council Resolution 780 (1992), www.his.com/ twarrick/commxyu4.htm\#III.A (19 January 2002). 